\title{
Determining Factors Affecting Acceptance of E-Learning Platforms during the COVID-19 Pandemic: Integrating Extended Technology Acceptance Model and DeLone \& McLean IS Success Model
}

\author{
Yogi Tri Prasetyo ${ }^{1, *}$, Ardvin Kester S. Ong 1,2 ${ }^{\mathbb{D}}$, Giero Krissianne Frances Concepcion ${ }^{3}$, \\ Francheska Mikaela B. Navata ${ }^{3}$, Raphael Andrei V. Robles ${ }^{3}$, Isaiash Jeremy T. Tomagos ${ }^{3}$, Michael Nayat Young ${ }^{1}$, \\ John Francis T. Diaz ${ }^{4}$, Reny Nadlifatin ${ }^{5}$ and Anak Agung Ngurah Perwira Redi ${ }^{6}$
}

1 School of Industrial Engineering and Engineering Management, Mapúa University, 658 Muralla St., Intramuros, Manila 1002, Philippines; aksong@mapua.edu.ph (A.K.S.O.); mnyoung@mapua.edu.ph (M.N.Y.)

2 School of Graduate Studies, Mapúa University, 658 Muralla St., Intramuros, Manila 1002, Philippines

3 Young Innovators Research Center, Mapúa University, 658 Muralla St., Intramuros, Manila 1002, Philippines; gfkconcepcion@mymail.mapua.edu.ph (G.K.F.C.); fmbnavata@mymail.mapua.edu.ph (F.M.B.N.); rvrobles@mymail.mapua.edu.ph (R.A.V.R.); ijtomagos@mymail.mapua.edu.ph (I.J.T.T.)

check for updates

Citation: Prasetyo, Y.T.; Ong, A.K.S.; Concepcion, G.K.F.; Navata, F.M.B.;

Robles, R.A.V.; Tomagos, I.J.T.; Young, M.N.; Diaz, J.F.T.; Nadlifatin, R.; Redi, A.A.N.P. Determining Factors Affecting Acceptance of E-Learning Platforms during the COVID-19

Pandemic: Integrating Extended Technology Acceptance Model and DeLone \& McLean IS Success Model. Sustainability 2021, 13, 8365. https://doi.org/10.3390/su13158365

Academic Editors:

Ebba Ossiannilsson and Aras Bozkurt

Received: 27 June 2021

Accepted: 20 July 2021

Published: 27 July 2021

Publisher's Note: MDPI stays neutral with regard to jurisdictional claims in published maps and institutional affiliations.

Copyright: (C) 2021 by the authors Licensee MDPI, Basel, Switzerland. This article is an open access article distributed under the terms and conditions of the Creative Commons Attribution (CC BY) license (https:/ / creativecommons.org/licenses/by/ $4.0 /)$.
4 Department of Finance and Accounting, Asian Institute of Management, 123 Paseo de Roxas, Legazpi Village, Makati, Metro, Manila 1229, Philippines; jdiaz@aim.edu

5 Department of Information Systems, Institut Teknologi Sepuluh Nopember, Kampus ITS Sukolilo, Surabaya 60111, Indonesia; reny.nadlifatin@gmail.com

6 BINUS Graduate Program-Master of Industrial Engineering, Industrial Engineering Department, Bina Nusantara University, Jakarta 11480, Indonesia; wira.redi@binus.edu

* Correspondence: ytprasetyo@mapua.edu.ph; Tel.: +63-(2)-8247-5000 (ext. 6202)

Abstract: Online meeting platforms have been widely utilized during the COVID-19 pandemic due to the current shift from traditional learning. However, the acceptance of the different online meeting platforms for e-learning has been underexplored. The purpose of this study was to determine the factors for acceptance of an online learning platform among students during the COVID-19 pandemic. A total of 500 senior high school students voluntarily participated to answer constructs under the Extended Technology Acceptance Model (ETAM) and Delone and McLean IS Success Model. Several latent including user interface (UI), perceived ease of use (PEU), perceived usefulness (PU), information quality (IQ), system quality (SQ), behavioral intentions (BI), and actual use were analyzed by Structural Equation Modeling (SEM). The results indicated that PEU was found to have the greatest on actual use (AU), followed by UI and SQ towards PEU, which subsequently led to BI and AU. Finally, IQ was found to have a significant effect on PU, which led to BI and AU. The level of student acceptability considers the ease of use, user interface, system quality, information quality, leading to a positive behavioral intention for actual use. With that, it would be of best interest to consider the factors that would lead students towards accepting the platforms utilized and therefore the current education system. Moreover, this will lead to their acceptance and promote learning even with the COVID-19 pandemic. Finally, the model construct can be applied and utilized to analyze the online learning platforms in other countries.

Keywords: distance learning; COVID-19; online meeting platforms; Extended Technology Acceptance Model; DeLone and McLean IS Success Model

\section{Introduction}

Worldwide education has been suspended due to the COVID-19 pandemic. Due to this pandemic, schools, universities, and other higher educational institutions temporarily paused face-to-face educational learning. The education learning is mainly delivered through online meeting platforms such as Blackboard Collaborate, Microsoft Teams, and 
Zoom. These online meeting platforms served as virtual learning environment where students could learn without going to school [1]. The purpose of utilizing these platforms is to ease the communication between students and teachers for education to continue. These platforms are also being introduced to promote a new type of education during the COVID-19 pandemic, which is widely known as e-Learning [2].

e-Learning is defined as a system-based formalized learning system that uses electronic resources. Electronic resources are digital materials such as e-journals, e-books, pre-recorded presentations, and online quizzes. These digital learning materials are uploaded through the internet where students and instructors can meet, discuss, and conduct class discussions virtually like in a classroom through an online meeting platform [3]. Like traditional learning, e-learning can give a sense of working in collaboration through online platforms giving a sense of 'togetherness'. The feeling of sharing the same physical space and time through online meeting platforms provides better communication between learners and instructors. The delivery of instructions, guidelines, and lectures could be done through virtual communication. With online meeting platforms, e-learning becomes efficient for students in keeping up with their studies even during the COVID-19 pandemic.

Reflective practices, reviews, participation, creativity and innovation, interactivity, receptive learnings, and demonstration have been conducted through these meeting platforms. However, the progressive development of e-learning has been underexplored since the COVID-19 lockdown occurred. With that, it is needed to utilize the current e-learning experience to evaluate the online meeting platforms being experienced by the students. Due to the abrupt change in the learning system, there may be a lot of improvements needed for a better learning experience. With better learning experience, students will be able to cope with the lessons being developed through the different online meeting platforms.

Previous studies have found that these online platforms have been considered within the literature with good outcomes [4]. With the quick growth of the computer network, engaging e-learning platforms have set up a large environment in online learning. They have abundant information of the attributes, force, and no time in space restrictions [5]. In addition, it is either used as a supplementary form of traditional learning or it is being used as a primary method for distance learning, especially with the COVID-19 pandemic that implemented lockdowns [2,6].

Despite the accessibilities of the online meeting platforms, it allowed the students and instructors to fulfill classroom learning without experiencing problems due to the COVID19 pandemic [1]. However, according to Hasan and Bao (2020), during the COVID-19 pandemic, there are digital learning inequalities. Digital inequality and a lack of access to new technologies were found to be difficult for students from low-income communities to navigate online lessons [7]. This indicates that low-income communities are strongly linked to psychological stress due to online lessons [7]. Furthermore, online learning platforms are given to the students, whereas numerous tools are accustomed to engaging students in individual learning [1]. Moreover, greater efforts have been invested in determining what would be the various factors that would affect the loyalty of online meeting platforms among senior high school students.

In the previous studies presented, there is strong evidence that online meeting platforms are very useful to students and teachers especially in this time of the COVID-19 pandemic $[4,8]$. However, only a few studies investigated the acceptance of online learning platforms during the COVID-19 pandemic. Most of the previous studies focused on e-learning success and psychological distress among students using online meeting platforms $[3,7]$. One of the most utilized theories to analyze the acceptance of a new platform is the Technology Acceptance Model (TAM).

Technology Acceptance Model is one of Information Systems (IS) researchers' most prominent and widely used model to predict the potential use of a product or technology [9]. According to Al-Fraihat et al. (2020), when users are provided with new technologies, several factors affect how and when they can use it [3]. For instance, only several studies 
have examined the responsibility of family support towards the technology adoption process of the students [10]. These studies integrated extended TAM, which is intended to affect intern convictions, perceptions, and intentions of students' family support, which has positively estimated the ease of use, usefulness, attitude to tablets as well as the intention of using tablet computers among students [10]. In addition, extended TAM is used to identify several factors that impact the behavior of users while utilizing a mobile library application [11]. The positive impact of the behavior considered perceived usefulness and perceived ease of use addressing the system quality [11]. Furthermore, TAM is commonly combined with several theories such as DeLone and McLean IS Model [12].

According to Hsu et al. (2014), the DeLone and McLean IS Success Model is used for IS research papers as a valid model and framework for variables that are complex dependent [12]. In addition, this model is developed and proposed to information systems to study what the user behavior is and explain it through the utilization of technology [13]. Moreover, this model is still widely used by researchers and journalists of the service industry because the comprehension and understanding about Information System Success are continuously progressing. Additionally, if a proper understanding of the model is achieved, it would help to show the importance of the system. It can even serve as the foundation for the decisions to the said systems [14]. The significance of the DeLone and McLean IS Success Model will contribute greatly as help to create new ideas and strategies that will further aid the students in developing countries on the adaptation to the use of e-learning platforms [15]. Therefore, the current adaptation of e-learning due to the COVID-19 pandemic should be explored. Specifically, the acceptance of students in utilizing online meeting platforms for e-learning.

The purpose of this study was to determine the factors contributing to the acceptance of an online learning platform among students during the COVID-19 pandemic. Extended Technology Acceptance Model (ETAM) and Delone and McLean IS Success Model were integrated to determine the causal relationships among the selected factors. This study contributed to the highlighting factors affecting online meeting platforms' loyalty among Filipino senior high school students during the COVID-19 pandemic. The result of this study could be utilized to give better experiences during E-learning in the COVID-19 pandemic. With the sudden shift of traditional learning to online learning, it would be best to consider the factors for acceptance of students toward different online meeting platforms. This will result in a better experience, thus enhancing learning among students during the COVID-19 pandemic lockdown. The model construct can also be applied and extended to analyze the online learning platforms in different countries.

\section{Literature Review and Hypotheses}

During the COVID-19 pandemic, only a few studies were conducted out from the Philippines. Moreover, only a few have used the Extended Technology Acceptance Model and the Delone and McLean IS Model. Hence, extending the research to other fields based on technology with a larger sample of study potentially appears to raise the current understanding regarding the use of IT applications [16]. From Figure 1, the extension of the Technology Acceptance Model included information quality, system quality, and user interface from the Delone and McLean IS Model. Following previous studies [3,9,16-19], the Delone and McLean IS Model could promote antecedent in measuring the actual use of a system through behavioral intentions. This is because system quality has a positive impact on e-learning [3], information quality can measure the performance and information towards e-learning [17,18], and the user interface is an antecedent of perceived ease of use that determines the interactivity among users $[16,19]$. Therefore, the relationship of the latent is presented in Figure 1. 


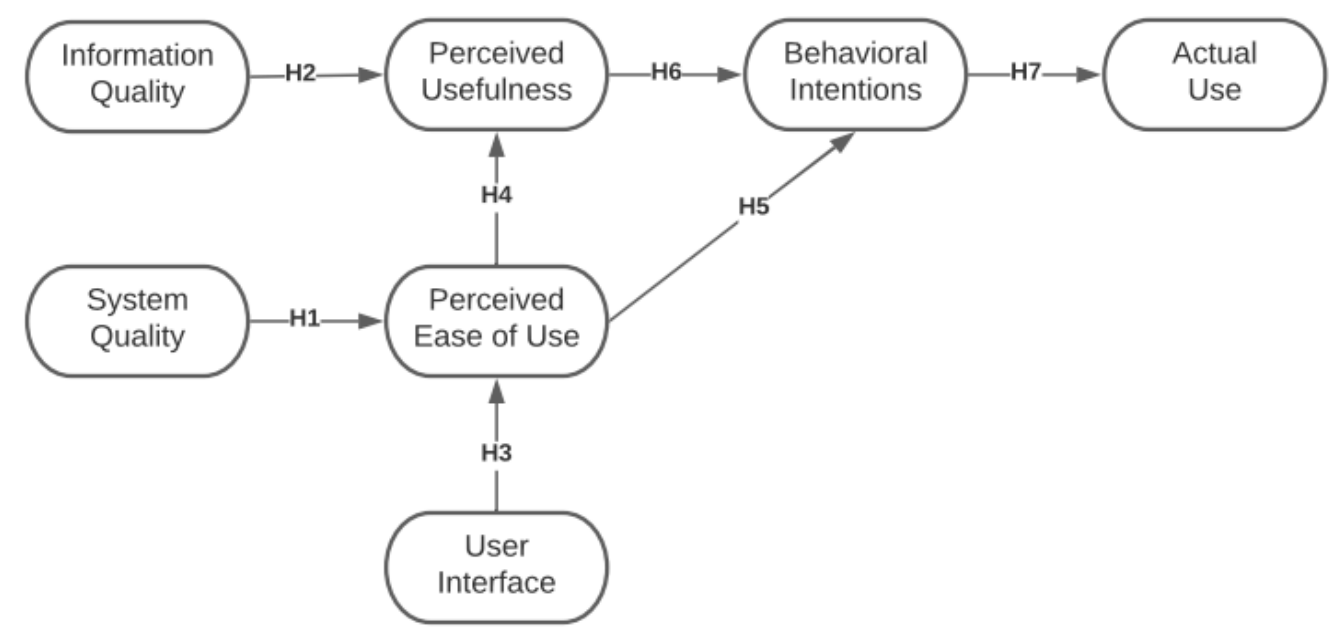

Figure 1. Theoretical research framework.

The connection of system quality and perceived ease of use were not empirically shown, as stated by Al-Fraihat [3]. According to [3], it is argued that the lack of support system quality is often aided to have a beneficial impact on the system and the understanding of an e-learning system among users. The ease of use should be considered for utilization of a system. Furthermore, given the presence of communication features, such as forums, messages, and email, data from messages and forums can convey the views and personal data that a student may not want to be recognized from the outside world through internet service providers. Therefore, providing details before using the technology or the system will improve their understanding and affect their attitudes significantly towards the overall utility of the system [3]. Thus, we hypothesized that:

Hypothesis 1. System quality had a significant direct effect on perceived ease of use.

Information quality is a key and essential factor in determining the performance of information and the e-learning environment. The information has an important role in achieving learning objectives and the severe challenges that have occurred as a result of low information quality [17]. In addition, $\mathrm{Wu}$ [18] observed the relationship between information quality and perceived usefulness is significant. Consequently, we can conclude that enhanced information quality in the e-learning environment can contribute to a growing degree of perceived usefulness. Thus, we hypothesized that:

Hypothesis 2. Information quality had a significant direct effect on perceived usefulness.

The most powerful feature of an online meeting platform is that it remains an interactive platform with various people. These experiences influenced students to keep using online meeting platforms [19]. According to Mohammadi [16], the user interface is where a person takes control over a technology or system. Moreover, it was figured out that learners are attracted by the usage of the features. The features would eventually improve the user's attractiveness as well as the reduction of the waiting and response time of the materials to load [16]. Thus, we hypothesized that:

Hypothesis 3. User interface had a significant direct effect on the perceived ease of use.

Furthermore, perceived usefulness and perceived ease of use are combined towards technology acceptance. According to Mohammadi [16], perceived ease of use is when an individual accepts that utilizing a system would be free of effort. It describes the behavior of an individual towards their interaction, which will serve as the mediator to the actual use of the system [16]. Moreover, perceived ease of use has been utilized to measure 
the end-user's behavioral intention of using a technology [9]. Behavioral intention is defined as the outcome of the behavior executed by an individual based on the individual's experience. With that, if the perceived ease of use of the online meeting platforms is greater, the intention of its usage is more beneficial. Hence, we proposed the following:

Hypothesis 4. Perceived ease of use had a significant direct effect on the perceived usefulness of online meeting platforms.

Hypothesis 5. Perceived ease of use had a significant direct effect on the behavioral intentions of the user.

Among the other models concerning the acceptance of technology, the Extended Technology Acceptance Model is utilized towards technology acceptance. It introduces the concepts of perceived usefulness (PU) and perceived ease of use (PEU) to measure the intentions of the user to use technology [9]. According to Zheng and Li [10], TAM indicates that the two variables (PE and PEU) influence the attitude of the students to use a new application, system, or technology. With that, the attitude of the students influences their behavioral intention to use. According to Mohammadi (2015), perceived usefulness is described as an important factor of intention, in which it persuades the users to accept a more advanced and user-friendly technology [16]. With that, if the perceived usefulness of the online meeting platforms is greater, the more effective is the intention towards its usage. Thus, we hypothesized that:

Hypothesis 6. Perceived usefulness had a significant direct effect on the behavioral intentions of the user.

Behavioral intention is defined as the motivational factors that influence a person to execute or not execute the behavior in the future. Moreover, according to Botero et al. [20], behavioral intention has a positive effect on actual usage. This connection has been proven in research covering technologies in education. Thus, we hypothesized that:

Hypothesis 7. Behavioral intention had a significant direct effect on actual use.

\section{Methodology}

\subsection{Questionnaire}

An online questionnaire (Table 1) was distributed through Google Forms since it is not possible to conduct surveys due to the General Community Quarantine (GCQ) of the COVID-19 pandemic in the Philippines. In accordance with other studies [21,22], an online questionnaire would suffice with the data collection for the study. The respondents were asked to answer the questions with the extent of their knowledge and experience. With our theoretical framework, a self-administered questionnaire was developed in our study to determine factors that affected the loyalty of online meeting platforms among Filipino senior high school students during the COVID-19 pandemic. The questionnaire consisted of 8 sections, which included demographic information, system quality, information quality, user interface, perceived usefulness, perceived ease of use, behavioral intentions, and actual use. A total of 32 questions adapted from different studies covered all factors. A test run was done utilizing 50 respondents to check the validity of the questionnaire. Following the suggestion of Hair [23], the overall result got a Cronbach's alpha value of 0.976 (acceptable $\geq 0.700$ ). Thus, the questionnaire was considered valid and was distributed. The demographic information consisted of questions regarding gender, school year, hours consumed in an online class (per week), and tuition fee (per year). A 5-point Likert scale was utilized in this study to measure all latent variables. The 5-point Likert scale had a measure of strongly disagree as 1 and strongly agree as 5 . 
Table 1. The construct and measurement items.

\begin{tabular}{|c|c|c|c|}
\hline Construct & Item & Measurements & References \\
\hline \multirow{5}{*}{ System Quality } & SYS1 & I find the online meeting platform easy to use. & [24] \\
\hline & SYS2 & $\begin{array}{l}\text { I find it flexible to communicate with the online } \\
\text { meeting platforms. }\end{array}$ & [16] \\
\hline & SYS3 & $\begin{array}{l}\text { I have a clear and understandable interaction with } \\
\text { online meeting platforms. }\end{array}$ & \\
\hline & SYS4 & $\begin{array}{l}\text { I feel comfortable using the online meeting platform } \\
\text { services and functionalities. }\end{array}$ & [25] \\
\hline & SYS5 & $\begin{array}{l}\text { The online meeting platform's interface and system } \\
\text { design is friendly. }\end{array}$ & [25] \\
\hline \multirow{5}{*}{ Information Quality } & IQ1 & $\begin{array}{l}\text { Online meeting platforms deliver useful information } \\
\text { to my needs. }\end{array}$ & \\
\hline & IQ2 & $\begin{array}{l}\text { Online meeting platforms offer exactly the } \\
\text { knowledge I need. }\end{array}$ & \\
\hline & IQ3 & $\begin{array}{l}\text { Online meeting platforms provide me knowledge } \\
\text { and organized content. }\end{array}$ & \\
\hline & IQ4 & $\begin{array}{l}\text { Online meeting platforms provide up-to-date } \\
\text { information and content. }\end{array}$ & \\
\hline & IQ5 & $\begin{array}{l}\text { Online meeting platforms provide accurate } \\
\text { information. }\end{array}$ & [26] \\
\hline \multirow{5}{*}{ Perceived Usefulness } & PU1 & $\begin{array}{l}\text { Online meeting platforms are very useful in this } \\
\text { time of pandemic. }\end{array}$ & \\
\hline & PU2 & $\begin{array}{l}\text { Online meeting platforms increase my productivity } \\
\text { in my academics. }\end{array}$ & \\
\hline & PU3 & $\begin{array}{c}\text { Online Meeting platforms make it easier to study in } \\
\text { distance learning. }\end{array}$ & \\
\hline & PU4 & $\begin{array}{l}\text { Online meeting platforms improve my performance } \\
\text { in my academics. }\end{array}$ & \\
\hline & PU5 & $\begin{array}{l}\text { Online meeting platforms enable me to study } \\
\text { asynchronously. }\end{array}$ & \\
\hline \multirow{4}{*}{ Perceived Ease of Use } & PEU1 & I find online meeting platforms to be easy to use. & \\
\hline & PEU2 & Online meeting platforms make me feel comfortable. & \\
\hline & PEU3 & $\begin{array}{c}\text { Online meeting platforms enhance my academic } \\
\text { performances }\end{array}$ & \\
\hline & PEU4 & $\begin{array}{l}\text { Online meeting platforms are much convenient for } \\
\text { me to use. }\end{array}$ & \\
\hline \multirow{5}{*}{ User Interface } & UI1 & $\begin{array}{l}\text { Online meeting platforms provide user-friendly } \\
\text { features. }\end{array}$ & \\
\hline & UI2 & $\begin{array}{l}\text { I found various features in the platform that were } \\
\text { well integrated. }\end{array}$ & \\
\hline & UI3 & I think I would like to use online meeting platforms. & \\
\hline & UI4 & $\begin{array}{l}\text { I would imagine myself that I would learn to use } \\
\text { this system very quickly. }\end{array}$ & \\
\hline & UI5 & $\begin{array}{l}\text { I think I would recommend to others to use online } \\
\text { meeting platforms. }\end{array}$ & \\
\hline \multirow{5}{*}{ Behavioral Intentions } & BI1 & I am motivated to use online meeting platforms. & \\
\hline & BI2 & I recommend using online meeting platforms. & \\
\hline & $\mathrm{BI} 3$ & $\begin{array}{l}\text { I am willing to use online meeting platforms for the } \\
\text { whole year. }\end{array}$ & \\
\hline & BI4 & I am very likely to use online meeting platforms. & \\
\hline & BI5 & $\begin{array}{c}\text { Using online meeting platforms makes online } \\
\text { learning interesting. }\end{array}$ & \\
\hline \multirow{3}{*}{ Actual Use } & AU1 & $\begin{array}{l}\text { I think everyone learns more when using online } \\
\text { meeting platforms. }\end{array}$ & \\
\hline & AU2 & $\begin{array}{l}\text { I think everyone has fast internet access to use } \\
\text { online meeting platforms. }\end{array}$ & \\
\hline & AU3 & $\begin{array}{l}\text { I think everyone has a good environment to use } \\
\text { online platforms. }\end{array}$ & \\
\hline
\end{tabular}




\subsection{Participants}

The participants were among senior high school students from any school in the Philippines. The participants voluntarily answered the questionnaire, which took about 15-20 min to accomplish. A total of 500 respondents were collected for this study. Hair [23] suggested that 500 respondents would suffice for a framework considering 8 or more latent. Additionally, the respondents were asked to fill out a consent form before answering the survey. Convenience sampling was utilized in this study wherein we made the link available for anyone to answer between October 2020 to December 2020. Specifically, the link of the Google form was distributed through social media platforms for all senior high school students. Therefore, any student from different universities had equal opportunity to answer with their prerogative.

Table 2 represents the descriptive statistics of the senior high school respondents in which the profile of the respondents was discussed; however, names were not included to protect privacy. Based on the results, $79 \%$ of the results show the percentage of grade 12 students that participated in this study while $21 \%$ of the results were grade 11 students. Moreover, results show that there was a greater percentage of students within a range of 31-40 $\mathrm{h}(29.5 \%)$ for their online classes. The tuition fee measured the socio-economic status of the respondents, wherein it was within the bracket of middle to higher economic status. The higher economic status was seen to be $50.3 \%$ of the respondents with more than $70,000 \mathrm{Php}$ of tuition fee per year. Following which is $28.4 \%$ in the middle status of $15-70,000$ Php and $21.4 \%$ of the lower socio-economic status.

Table 2. Descriptive statistics of the respondents $(n=500)$.

\begin{tabular}{cccc}
\hline Characteristics & Category & $\mathbf{N}$ & $\%$ \\
\hline \multirow{3}{*}{ Gender } & Male & 210 & $42.1 \%$ \\
& Female & 277 & $55.3 \%$ \\
& Prefer not to say & 11 & $2.2 \%$ \\
& Other & 2 & $0.4 \%$ \\
\hline \multirow{2}{*}{ School Year } & Grade 11 & 104 & $21 \%$ \\
& Grade 12 & 396 & $79 \%$ \\
\hline \multirow{2}{*}{ Hours Consumed in Online Classes (Per Week) } & Less than 10 & 98 & $19.6 \%$ \\
& $10-20$ & 84 & $16.8 \%$ \\
& $21-30$ & 77 & $15.4 \%$ \\
& $31-40$ & 147 & $29.5 \%$ \\
& More than 40 & 94 & $18.8 \%$ \\
\hline \multirow{2}{*}{ Tuition Fee (Per Year) } & Less than P15,000 & 107 & $21.4 \%$ \\
& P15,000-P70,000 & 141 & $28.3 \%$ \\
& More than & 252 & $50.3 \%$ \\
\hline
\end{tabular}

\subsection{Statistical Analysis}

Structural Equation Modeling (SEM) is a quantitative tool that is commonly utilized in advertising and institutional behavior analysis for instrument validation and model testing [27]. In addition, it can be used for evaluating the relationship between the numbers observed and the latent variables [28]. According to Teo and Noyes [29], SEM can be used for assessing and analyzing the intentions and behavior of the user on the usage of technology. In the study, SEM was utilized to explain and estimate the factors that influenced senior high students to choose an e-learning platform and their acceptance.

\section{Results}

Figure 2 demonstrates the initial SEM with indicators on the analysis for evaluating the factors affecting online meeting platforms' acceptance and loyalty. As seen in the model, three indicators had low significance, therefore modification indices were applied 
to enhance the model fit [23]. Figure 3 demonstrates the final SEM analysis for evaluating the factors affecting online meeting platforms' loyalty.

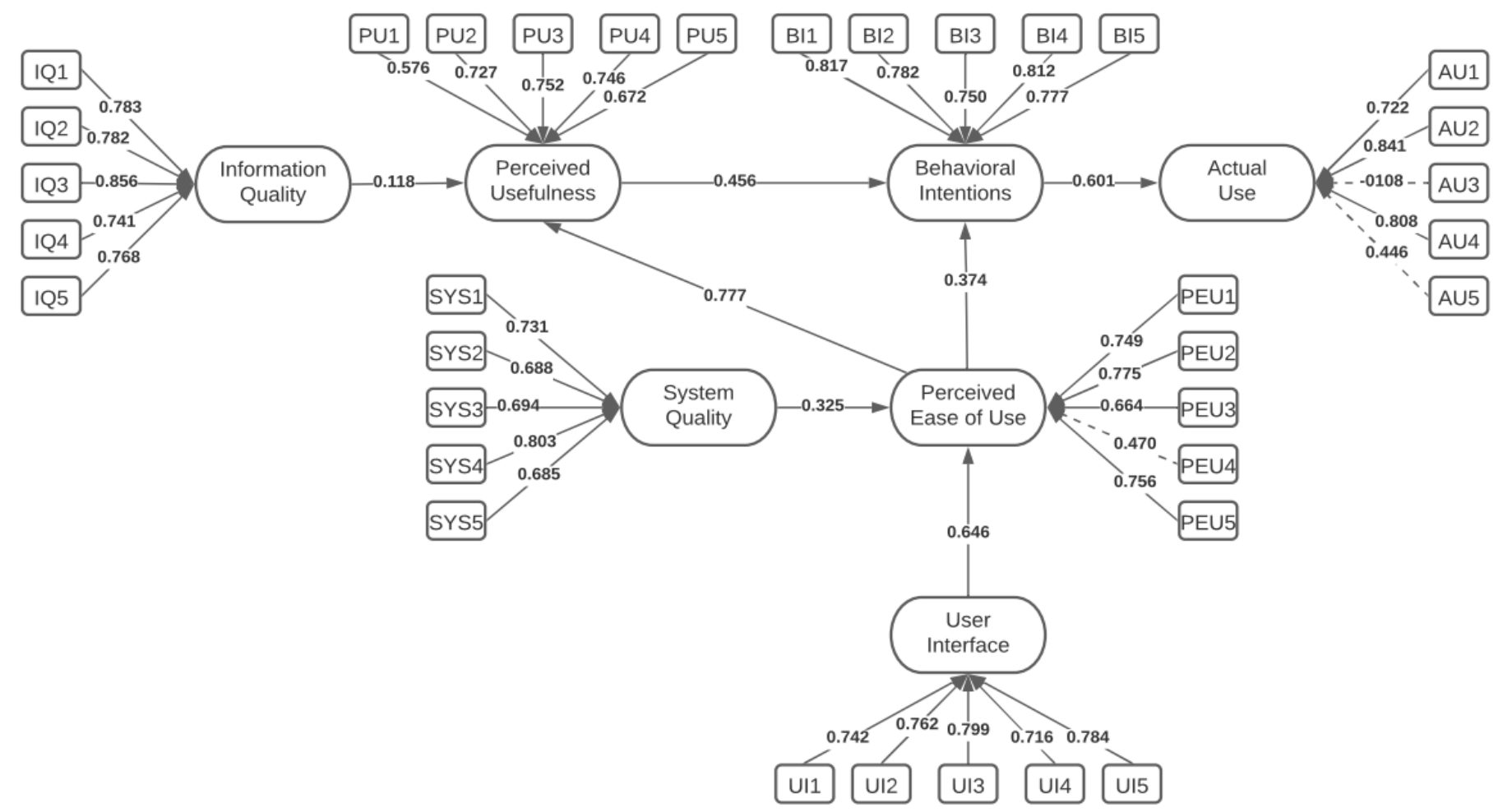

Figure 2. The Initial SEM analysis for evaluating the factors affecting online meeting platforms' loyalty.

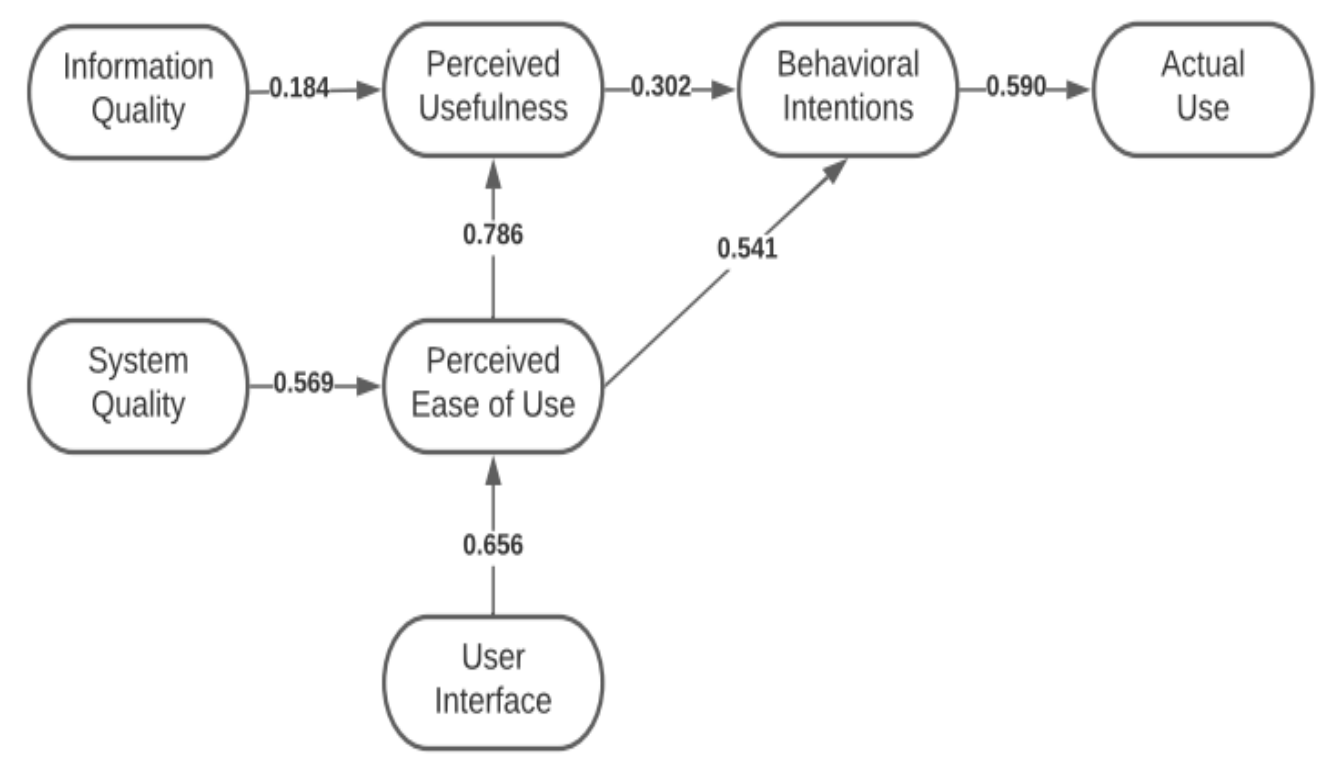

Figure 3. The final SEM analysis for evaluating the factors affecting online meeting platforms' loyalty.

Demonstrated in Table 3 are the results of the descriptive statistics for the constructs utilized in this study. Table 4 shows the reliability and validity of the constructs. Average Variance Extracted (AVE) measures the discriminant validity of the constructs. A construct with an AVE greater than 0.5 indicates a degree of validity in the construct [23,30]. Cronbach $\alpha$ and Composite Reliability (CR) both measure the internal consistency between each set of items in a construct with an acceptable value of greater than 0.700 [23,31]. All constructs used in this study had values greater than 0.800 , and thus were considered acceptable. 
Table 3. Indicators statistical analysis.

\begin{tabular}{|c|c|c|c|c|c|}
\hline \multirow[b]{2}{*}{ Factor } & \multirow[b]{2}{*}{ Item } & \multirow[b]{2}{*}{ Mean } & \multirow[b]{2}{*}{ StD } & \multicolumn{2}{|c|}{ Factor Loading } \\
\hline & & & & Initial Model & Final Model \\
\hline \multirow{5}{*}{$\begin{array}{l}\text { System } \\
\text { Quality }\end{array}$} & SYS1 & 3.534 & 1.1293 & 0.731 & 0.753 \\
\hline & SYS2 & 3.232 & 1.0884 & 0.688 & 0.698 \\
\hline & SYS3 & 3.152 & 1.0541 & 0.694 & 0.713 \\
\hline & SYS4 & 3.182 & 1.0804 & 0.803 & 0.808 \\
\hline & SYS5 & 3.618 & 1.0345 & 0.685 & 0.613 \\
\hline \multirow{5}{*}{$\begin{array}{c}\text { Information } \\
\text { Quality }\end{array}$} & IQ1 & 3.536 & 0.9688 & 0.783 & 0.767 \\
\hline & IQ2 & 3.100 & 1.0238 & 0.782 & 0.760 \\
\hline & IQ3 & 3.334 & 1.0102 & 0.856 & 0.863 \\
\hline & IQ4 & 3.636 & 0.9846 & 0.741 & 0.747 \\
\hline & IQ5 & 3.530 & 0.9669 & 0.768 & 0.750 \\
\hline \multirow{5}{*}{$\begin{array}{l}\text { Perceived } \\
\text { Usefulness }\end{array}$} & PU1 & 4.174 & 1.0168 & 0.576 & 0.575 \\
\hline & PU2 & 2.860 & 1.1397 & 0.727 & 0.620 \\
\hline & PU3 & 3.306 & 1.2536 & 0.752 & 0.673 \\
\hline & PU4 & 2.794 & 1.1411 & 0.746 & 0.652 \\
\hline & PU5 & 3.216 & 1.1714 & 0.672 & 0.581 \\
\hline \multirow{5}{*}{$\begin{array}{c}\text { Perceived } \\
\text { Ease of Use }\end{array}$} & PEU1 & 3.606 & 1.1105 & 0.749 & 0.698 \\
\hline & PEU2 & 3.038 & 1.1041 & 0.775 & 0.667 \\
\hline & PEU3 & 2.758 & 1.0945 & 0.664 & 0.686 \\
\hline & PEU4 & 2.380 & 1.2581 & 0.470 & - \\
\hline & PEU5 & 3.056 & 1.1012 & 0.756 & 0.656 \\
\hline \multirow{5}{*}{$\begin{array}{c}\text { User } \\
\text { Interface }\end{array}$} & UI1 & 3.644 & 0.9732 & 0.742 & 0.836 \\
\hline & UI2 & 3.566 & 0.9051 & 0.762 & 0.844 \\
\hline & UI3 & 3.008 & 1.1622 & 0.799 & 0.912 \\
\hline & UI4 & 3.228 & 1.2178 & 0.716 & 0.630 \\
\hline & UI5 & 3.138 & 1.1531 & 0.784 & 0.933 \\
\hline \multirow{5}{*}{$\begin{array}{l}\text { Behavioral } \\
\text { Intentions }\end{array}$} & BI1 & 2.806 & 1.1344 & 0.817 & 0.778 \\
\hline & $\mathrm{BI} 2$ & 3.050 & 1.1533 & 0.782 & 0.757 \\
\hline & $\mathrm{BI} 3$ & 2.658 & 1.3009 & 0.750 & 0.696 \\
\hline & $\mathrm{BI} 4$ & 2.976 & 1.1180 & 0.812 & 0.758 \\
\hline & BI5 & 2.726 & 1.1890 & 0.777 & 0.731 \\
\hline \multirow{5}{*}{ Actual Use } & AU1 & 2.250 & 1.1533 & 0.722 & 0.857 \\
\hline & AU2 & 1.690 & 1.0846 & 0.841 & 0.667 \\
\hline & AU3 & 4.158 & 1.1832 & -0.108 & - \\
\hline & AU4 & 1.882 & 1.1002 & 0.808 & 0.613 \\
\hline & AU5 & 3.120 & 1.1817 & 0.446 & - \\
\hline
\end{tabular}

Table 5 demonstrated the IFI, TLI, CFI, GFI, AGFI, and RMSEA. From the study of Gefen et al. [30] and Steiger [31], values higher than 0.80 for TLI, IFI, CFI, GFI, and AGFI $\mathrm{f}$ and a value less than for 0.07 RMSEA are considered good model fit [32,33]. Based on Table 5, all the model fits passed the cut-off, indicating that the model was a good presentation of the data. 
Table 4. Reliability and Validity.

\begin{tabular}{|c|c|c|c|c|c|}
\hline \multirow{2}{*}{ Factor } & \multicolumn{2}{|c|}{ Factor Loading } & \multirow{2}{*}{$\begin{array}{c}\text { Cronbach's } \\
\alpha\end{array}$} & \multirow{2}{*}{$\begin{array}{c}\text { Average Variance } \\
\text { Extracted (AVE) }\end{array}$} & \multirow{2}{*}{$\begin{array}{c}\text { Composite } \\
\text { Reliability (CR) }\end{array}$} \\
\hline & Initial & Final & & & \\
\hline \multirow{5}{*}{$\begin{array}{l}\text { System } \\
\text { Quality }\end{array}$} & 0.731 & 0.753 & \multirow{5}{*}{0.843} & \multirow{5}{*}{0.518} & \multirow{5}{*}{0.842} \\
\hline & 0.688 & 0.698 & & & \\
\hline & 0.694 & 0.713 & & & \\
\hline & 0.803 & 0.808 & & & \\
\hline & 0.685 & 0.613 & & & \\
\hline \multirow{5}{*}{$\begin{array}{l}\text { Information } \\
\text { Quality }\end{array}$} & 0.783 & 0.767 & \multirow{5}{*}{0.890} & \multirow{5}{*}{0.606} & \multirow{5}{*}{0.885} \\
\hline & 0.782 & 0.760 & & & \\
\hline & 0.856 & 0.863 & & & \\
\hline & 0.741 & 0.747 & & & \\
\hline & 0.768 & 0.750 & & & \\
\hline \multirow{5}{*}{$\begin{array}{l}\text { Perceived } \\
\text { Usefulness }\end{array}$} & 0.576 & 0.575 & \multirow{5}{*}{0.821} & \multirow{5}{*}{0.386} & \multirow{5}{*}{0.758} \\
\hline & 0.727 & 0.620 & & & \\
\hline & 0.752 & 0.673 & & & \\
\hline & 0.746 & 0.652 & & & \\
\hline & 0.672 & 0.581 & & & \\
\hline \multirow{5}{*}{$\begin{array}{l}\text { Perceived } \\
\text { Ease of Use }\end{array}$} & 0.749 & 0.698 & \multirow{5}{*}{0.818} & \multirow{5}{*}{0.458} & \multirow{5}{*}{0.771} \\
\hline & 0.775 & 0.667 & & & \\
\hline & 0.664 & 0.686 & & & \\
\hline & 0.470 & - & & & \\
\hline & 0.756 & 0.656 & & & \\
\hline \multirow{5}{*}{$\begin{array}{c}\text { User } \\
\text { Interface }\end{array}$} & 0.742 & 0.836 & \multirow{5}{*}{0.869} & \multirow{5}{*}{0.426} & \multirow{5}{*}{0.748} \\
\hline & 0.762 & 0.844 & & & \\
\hline & 0.799 & 0.912 & & & \\
\hline & 0.716 & 0.630 & & & \\
\hline & 0.784 & 0.933 & & & \\
\hline \multirow{5}{*}{$\begin{array}{l}\text { Behavioral } \\
\text { Intentions }\end{array}$} & 0.817 & 0.778 & \multirow{5}{*}{0.889} & & \\
\hline & 0.782 & 0.757 & & & \\
\hline & 0.750 & 0.696 & & 0.554 & 0.861 \\
\hline & 0.812 & 0.758 & & & \\
\hline & 0.777 & 0.731 & & & \\
\hline & 0.722 & 0.857 & & & \\
\hline & 0.841 & 0.667 & & & \\
\hline Actual Use & -0.108 & - & 0.830 & 0.518 & 0.760 \\
\hline & 0.808 & 0.613 & & & \\
\hline & 0.446 & - & & & \\
\hline Overall & uestionn & & 0.958 & - & 0.999 \\
\hline
\end{tabular}

Table 5. Model Fit.

\begin{tabular}{cccc}
\hline Goodness of Fit Measures of SEM & $\begin{array}{c}\text { Parameter } \\
\text { Estimates }\end{array}$ & $\begin{array}{c}\text { Minimum } \\
\text { Cut-Off }\end{array}$ & $\begin{array}{c}\text { Suggested } \\
\text { by }\end{array}$ \\
\hline Incremental Fit Index (IFI) & 0.852 & $>0.80$ & {$[30]$} \\
Tucker Lewis Index (TLI) & 0.857 & $>0.80$ & {$[30]$} \\
Comparative Fit Index (CFI) & 0.861 & $>0.80$ & {$[30]$} \\
Goodness of Fit Index (GFI) & 0.816 & $>0.80$ & {$[30]$} \\
Adjusted Goodness of Fit Index (AGFI) & 0.803 & $>0.80$ & {$[30]$} \\
Root Mean Square Error (RMSEA) & 0.065 & $<0.07$ & {$[31]$} \\
\hline
\end{tabular}

\section{Discussion}

The current study integrated the Extended Technology Acceptance Model and Delone and McLean IS Success Model to evaluate the factors affecting online meeting platform loyalty among Filipino senior high school students during the General Community Quaran- 
tine (GCQ) of the COVID-19 pandemic in the Philippines. A Structural Equation Modelling (SEM) approach was utilized in this study to analyze the interrelationship among the latent variables. The variables considered were system quality (SYS), information quality $(\mathrm{IQ})$, user interface (UI), perceived usefulness (PU), perceived ease of use (PEU), behavioral intentions (BI), and actual use (AU). With that, an online questionnaire was utilized through Google Forms. As a result, a total of 500 data samples were collected. Through the Structural Equation Modelling (SEM) approach, the impacts of these factors were examined.

The Technology Acceptance Model (TAM) was composed of perceived ease of use and perceived usefulness, which were the core variables of this model [10]. With that, Mohammadi [16] claimed that perceived usefulness is affected directly by perceived ease of use. As the result of the current study suggests, SEM indicated that perceived ease of use had a significant direct effect on perceived usefulness $(\beta=0.786$ and $p=0.001)$. Meanwhile, perceived ease of use serves as a mediator towards behavioral intentions. Perceived ease of use had no significant effects on students' intention from the study of Mohammadi [16]. In contrast with that, the findings of the current study indicate that SEM indicated that perceived ease of use had a significant direct effect on the behavioral intentions of the user ( $\beta=0.451$ and $p=0.001$ ). From the constructs, the students assessed that the ability of a system to be user-friendly, making users aware of any changes in the time of session through emails and social networks, the possibility of recording each session and uploading it in the database of the e-learning system for the absent users, and the overall usefulness were the main contributors to perceived usefulness and behavioral intentions [11,16]. The findings could be interpreted that the ease of use towards online meeting platforms makes it easier for students to study through remote learning. The results also suggest that online meeting platforms are very useful in this time of the pandemic. However, this may be challenging for students with limited access to the internet. According to Abuhassna et al. [34], students would tend to find information online, utilize online learning like platforms, and communicate with others to aid their learning. The challenge of digital inequalities appears when students need to gain information with a weak internet connection. Therefore, interactivity, receptive learnings, and demonstrations may be a challenge for students with weaker internet connections.

The user interface has a major effect when it comes to the perceived ease of use on technology ( $\beta=0.656$ and $p=0.001)$. This is supported by the results of the study from [35]. Perceived ease of use dictates if users decide if they are going to use technology for shortor long-term periods [36]. Additionally, the constructs indicated that users tend to be more at ease if they find an interface easy to use. Uploading pre-prepared content such as PowerPoint presentations, image files, documents, live-streaming, video content from a webcam, digital whiteboard, and screen and audio sharing were the main contributors to perceived ease of use. These findings were supported by the studies of [16,37], wherein they stated that the flexibility, time-efficient, responsiveness, functionality, and reliability helped in improving the user's attractiveness as well as the reduction of the waiting and response time of the materials to load $[16,38]$. Based on the data given in the results, Structural Equation Modeling (SEM) indicated that user interface has a strong direct effect on perceived ease of use. It means that the students are highly affected by the online meeting platform's user interface. However, this may only be applicable for students with moderate to strong internet connections. Therefore, it will be a challenge to perform reflective practices, reviews, apply creativity, innovation, and participations. Therefore, the user interface should be considered when being utilized in the current e-learning for students.

Furthermore, the behavioral intentions of a person play a significant part in the actual use of modern technologies [38]. The Technology Acceptance Model (TAM) indicates the behavioral intention of users forms the actual use of technology (AU). Additionally, when the behavioral intention is strong, the perception of information and communication technology (ICT) as a tool of teaching-learning should be reflected in its actual use of the 
Internet to teach [37]. In addition, the correlation between behavioral intention to use modern technologies and actual use involves experimentation to correct the high emphasis on behavioral intention, otherwise called the problem of the "bottleneck" $[39,40]$. Budu et al. [40] claimed as well that the outcome of their research shows that behavioral Intention positively impacts e-learning system application (actual use) [38]. The coefficient in the result of their study was $0.483(p<0.000)$, and thus, behavioral intention is supported. Based on the results of the current study, Structural Equation Modeling (SEM) indicated that behavioral intention has a significant direct effect on actual use ( $\beta=0.590$ and $p=0.001)$. Therefore, student's intention towards using an e-learning platform can be related to the interface and ease of use to have positive intentions of using the platform.

Perceived usefulness influences the attitude of students in using a new system or technology, then the attitude of students eventually affects their behavioral intention [10]. Additionally, online meeting platforms' effectiveness, productivity, and improvement in academics, as well as, studying asynchronously are the main contributors of perceived usefulness. In the study conducted by Islam [41], the researchers found that perceived usefulness is recognized as an unimportant factor in the use of e-learning. Moreover, according to Park et al. [42], the result of their study indicated that perceived usefulness had no significant direct effect on the behavioral intention of students. However, the studies mentioned did not have a pandemic when it was conducted [41,42]. Based on the results of the current study, the SEM indicated that perceived usefulness has a significant direct effect on behavioral intentions ( $\beta=0.302$ and $p=0.001$ ). This is because the current set-up of distant learning utilizes internet access to different platforms for continuous education. It was seen that there were high indicators of the system being useful in the current COVID-19 pandemic, and that students would rather utilize the online platform than risking infection, causing significance to the variable. This is also applicable for students in different countries by having e-learning as the substitute to traditional learning in the interests of safety.

According to Alsabawy et al. [17], system quality and information quality were considered as high factors in the successful design of e-learning systems. Moreover, the result of the study of Rafique et al. [11] indicated that system quality is a worthy interpreter to both perceived ease of use and perceived usefulness. However, $\mathrm{Wu}$ [18] claimed that system quality has no significant positive influence on perceived usefulness, but it has a significant positive influence on perceived ease of use. Furthermore, $\mathrm{Wu}$ [18] also claimed that information quality has a significant positive influence on perceived ease of use. Based on the results, Structural Equation Modeling (SEM) indicated that system quality had a significant direct effect on perceived ease of use $(\beta=0.569$ and $p=0.001)$. Therefore, students would tend to accept e-learning platforms that are convenient and easy to use.

According to Kim and Lee [43], system quality is one of the major factors that affect the perceived ease of use for how it determines how users will accept a system for its overall performance. Like the constructs considered in this study, adaptability, reliability, usefulness, and responsiveness are factors that highlight how students will be able to accept the different e-learning platforms. In addition, information quality was also found to have a significant direct effect on perceived usefulness. Information quality will determine if the information that will be given by the system is verified and accepted by the user, hence, it will affect the user's satisfaction, the intent of use, and perceived usefulness [44]. Additionally, accuracy, uniqueness, completeness, relevance, accessibility, precision, and informativeness of the information given is a major factor to the user's perceived usefulness [45]. Therefore, information quality had a significant direct effect on perceived usefulness ( $\beta=0.184$ and $p=0.001)$.

Apart from the significant direct effects, it could be interpreted that the online meeting platforms are useful as a medium to deliver information. It is inferred that the qualities of information that online meeting platforms deliver are enough and provide complete information, which make the students believe that the information provided is useful and helpful. These results could be considered for students' acceptance across the world. 
Different platforms may be utilized by different countries, that is why this study considered general constructs to measure student's acceptability. The level of student acceptability considers the ease of use, user interface, system quality, information quality, leading to a positive behavioral intention for actual use. Since the world is currently suffering from the COVID-19 pandemic, countries are in lockdown and therefore continue with the e-learning platforms. With that, it would be of best interest to consider the factors that would lead students towards accepting the platforms utilized and therefore the current education system. Moreover, this will lead to their acceptance and promote learning even with the COVID-19 pandemic.

\subsection{Theoretical Contributions}

According to Yakubu and Dasuki [15], the Structural Equation Modeling is a collection of methods and techniques that are commonly used to analyze and eventually explain the connection between multiple variables using a series of equations and computations. Additionally, SEM can analyze the most complex linkages between latent factors [46-51]. Because of this, SEM can be used for analyzing the factors on why the users use technology in the first place [52,53]. With this current pandemic, it is not a surprise that almost everyone will depend on the usage of technology, especially in the sector of education. In this study, the Structural Equation Modeling was utilized in such a way that it explains how Filipino senior high students will choose a specific online meeting platform by analyzing each individual factor and its relationship with each other. Moreover, the theoretical contribution of this study will be beneficial for both students and teachers when it comes to continuous learning, especially during the pandemic. By being able to have ease of use, interactivity for user interface, system and information quality among the platforms being utilized would lead to a positive behavioral intention for actual use.

\subsection{Practical Implication}

Due to the COVID 19 pandemic, traditional classroom learning has now progressed to online education, resulting in an eventual shift of all sorts of various educational institutions worldwide, which many Filipino students find difficult to adapt to [9]. The practical implications of the study provide insights into important issues and strategies that will broaden the significance of online meeting platforms among Filipino senior high school students. Online meeting platforms should enable communication and coordination between students to be expressed, thus affecting the satisfaction of learners [37]. The findings of the study can be useful for government officials and non-profit organizations to help and manage Filipino students with unequal learning opportunities from low-income communities that cannot access the new technologies used in online learning. Moreover, teachers and students could have a more efficient way of conducting online learning that would benefit both by utilizing a platform applicable for their liking and needs.

\subsection{Limitations and Future Research}

However, this paper still has limitations of some sort. Due to the utilization of online surveys, there may have been biases towards respondents with access to proper internet only. Future research can collect more data in a group and consider the differences in age, grade level, and gender. This may have an effect on the perception of the different online meeting platforms being utilized. Moreover, the prior experience of online learning may also be included for measurement for assessing the acceptance of e-learning platforms. Different students may have different perceptions and comfort with the online meeting platforms. Second, the different subjects taught were not considered. This may also be an extension by future researches as the different subjects are taught in different manners and approaches. Even the instructors or teachers may also be considered as a variable in this study. The delivery of instructions and lessons to the students may also be different. Third, this paper only studies the factors affecting online meeting platforms' loyalty among Filipino senior high school students. Junior high school students and teachers can also 
be future participants. Future studies can fully examine all the students' and teachers' loyalty among online meeting platforms. Lastly, the current study is only limited to the Philippines. Therefore, future studies can examine different countries to know different factors affecting online meeting platforms' loyalty among students around the world.

\section{Conclusions}

Online meeting platforms have been widely utilized during the COVID-19 pandemic. The need to continue developing the education system was challenged during the COVID19 pandemic. Specifically, it was seen that the sudden change in the mode of delivery from traditional learning to fully online became a challenge. The challenge led to the idea that online learning was considered an emergency education. With that, online learning highlighted a lot of issues with regard to sustainable learning. Different strategies came about to be developed as the new normal continues. The investment to promote and sustain the new normal mode of delivery for education could be promising with the proper communication tool to deliver the proper education needed. With established platforms and mode of delivery, online learning could eventually be considered as a mode of learning even after the COVID-19 pandemic. This option would lead to the adaptation and the extension of the sustainability goal (SDG4), growth and sustainability for education in the future. Following the suggestion of Steinberger et al. [48], no students will be left behind. Therefore, the need to assess the acceptance of e-learning platforms by students may be a start in determining sustainable education that may affect the future of e-learning.

Considering this, the purpose of this study was to determine the factors contributing to the acceptance of an online learning platform among Filipino students. Structural Equation Modeling was utilized with 32 indicators among different latent. The user interface, perceived ease of use, perceived usefulness, information quality, system quality, and behavioral intentions to actual use were the variables considered and were all found to be significant. Among the 500 respondents of Filipino senior high school students gathered online through convenience sampling, it was seen that perceived ease of use (PEU) was found to have the greatest significant effects on perceived usefulness towards actual use (AU). Following that is the user interface having a significant effect on PEU, and behavioral intentions to AU. Students want to utilize a system that is easy to use and for the interface to have high functionality and flexibility. The level of student acceptability considers the ease of use, user interface, system quality, information quality, leading to a positive behavioral intention for actual use. Since the world is currently suffering from the COVID-19 pandemic, countries are in lockdown and therefore continue with e-learning platforms. With that, it would be of interest to consider the factors that would lead students towards accepting the platforms utilized and therefore the current education system.

Author Contributions: Conceptualization, Y.T.P. and A.K.S.O.; methodology, Y.T.P. and A.K.S.O.; software, Y.T.P. and A.K.S.O.; validation, Y.T.P. and A.K.S.O.; formal analysis, Y.T.P. and A.K.S.O.; investigation, Y.T.P. and A.K.S.O.; resources, G.K.F.C., F.M.B.N., R.A.V.R., and I.J.T.T.; data curation, G.K.F.C., F.M.B.N., R.A.V.R., and I.J.T.T.; writing-original draft preparation, G.K.F.C., F.M.B.N., R.A.V.R., and I.J.T.T.; writing-review and editing, Y.T.P., A.K.S.O., M.N.Y., J.F.T.D., R.N., and A.A.N.P.R.; visualization, Y.T.P.; supervision, Y.T.P., M.N.Y., J.F.T.D., R.N., and A.A.N.P.R.; project administration, Y.T.P.; funding acquisition, Y.T.P. and M.N.Y. All authors have read and agreed to the published version of the manuscript.

Funding: This research was funded by Mapúa University Directed Research for Innovation and Value Enhancement (DRIVE).

Institutional Review Board Statement: This study was approved by the School of Industrial Engineering and Engineering Management Mapua University Research Ethics Committees.

Informed Consent Statement: Informed consent was obtained from all subjects involved in the study.

Data Availability Statement: The data presented in this study are available on request from the corresponding author. 
Acknowledgments: The authors would like to thank all the respondents who voluntary participated in this study.

Conflicts of Interest: The authors declare no conflict of interest.

\section{References}

1. Andel, S.A.; De Vreede, T.; Spector, P.E.; Padmanabhan, B.; Singh, V.K.; De Vreede, G.-J. Do social features help in video-centric online learning platforms? A social presence perspective. Comput. Hum. Behav. 2020, 113, 106505. [CrossRef]

2. Lee, D.Y.; Lehto, M.R. User acceptance of YouTube for procedural learning: An extension of the Technology Acceptance Model. Comput. Educ. 2013, 61, 193-208. [CrossRef]

3. Al-Fraihat, D.; Joy, M.; Sinclair, J. Evaluating E-learning systems success: An empirical study. Comput. Hum. Behav. 2020, 102, 67-86. [CrossRef]

4. Wlodarczyk, J.R.; Wolfswinkel, E.M.; Carey, J.N. Coronavirus 2019 video conferencing: Preserving resident education with online meeting platforms. Plast. Reconstr. Surg. 2020, 146, 110-111. [CrossRef]

5. Gašević, D.; Kovanović, V.; Joksimović, S.; Siemens, G. Where is research on massive open online courses headed? A data analysis of the MOOC Research Initiative. Int. Rev. Res. Open Distrib. Learn. 2014, 15, 134-176.

6. Zhan, Z.; Xu, F.; Ye, H. Effects of an online learning community on active and reflective learners' learning performance and attitudes in a face-to-face undergraduate course. Comput. Educ. 2011, 56, 961-968. [CrossRef]

7. Hasan, N.; Bao, Y. Impact of "e-Learning crack-up" perception on psychological distress among college students during COVID-19 pandemic: A mediating role of "fear of academic year loss". Child. Youth Serv. Rev. 2020, 118, 105355. [CrossRef] [PubMed]

8. Chen, T.; Peng, L.; Yin, X.; Rong, J.; Yang, J.; Cong, G. Analysis of user satisfaction with online education platforms in China during the COVID-19 pandemic. Healthcare 2020, 8, 200. [CrossRef] [PubMed]

9. Pal, D.; Vanijja, V. Perceived usability evaluation of Microsoft Teams as an online learning platform during COVID-19 using system usability scale and technology acceptance model in India. Child. Youth Serv. Rev. 2020, 119, 105535. [CrossRef]

10. Zheng, J.; Li, S. What drives students' intention to use tablet computers: An extended technology acceptance model. Int. J. Educ. Res. 2020, 102, 101612. [CrossRef]

11. Rafique, H.; Almagrabi, A.O.; Shamim, A.; Anwar, F.; Bashir, A.K. Investigating the acceptance of mobile library applications with an extended technology acceptance model (TAM). Comput. Educ. 2020, 145, 103732. [CrossRef]

12. Hsu, M.-H.; Chang, C.-M.; Chu, K.-K.; Lee, Y.-J. Determinants of repurchase intention in online group-buying: The perspectives of DeLone \& McLean IS success model and trust. Comput. Hum. Behav. 2014, 36, 234-245.

13. Aldholay, A.H.; Isaac, O.; Abdullah, Z.; Ramayah, T. The role of transformational leadership as a mediating variable in DeLone and McLean information system success model: The context of online learning usage in Yemen. Telemat. Inform. 2018, 35, 1421-1437. [CrossRef]

14. Ojo, A.I. Validation of the DeLone and McLean information systems success model. Healthc. Inform. Res. 2017, 23, 60. [CrossRef]

15. Yakubu, M.N.; Dasuki, S. Assessing eLearning systems success in Nigeria: An application of the DeLone and McLean information systems success model. J. Inf. Technol. Educ. Res. 2018, 17, 183-203. [CrossRef]

16. Mohammadi, H. Investigating users' perspectives on e-learning: An integration of TAM and IS success model. Comput. Hum. Behav. 2015, 45, 359-374. [CrossRef]

17. Alsabawy, A.Y.; Cater-Steel, A.; Soar, J. Determinants of perceived usefulness of e-learning systems. Comput. Hum. Behav. 2016, 64, 843-858. [CrossRef]

18. Wu, M.-C. A Study on University Students' Intention to Use the Digital Museum of Sports Literature. J. Int. Manag. Stud. 2013, 8 , 7-30.

19. Hart, T.; Bird, D.; Farmer, R. Using blackboard collaborate, a digital web conference tool, to support nursing students placement learning: A pilot study exploring its impact. Nurse Educ. Pract. 2019, 38, 72-78. [CrossRef]

20. Botero, G.G.; Questier, F.; Cincinnato, S.; He, T.; Zhu, C. Acceptance and usage of mobile assisted language learning by higher education students. J. Comput. High. Educ. 2018, 30, 426-451. [CrossRef]

21. Abrahim, S.; Mir, B.A.; Suhara, H.; Mohamed, F.A.; Sato, M. Structural equation modeling and confirmatory factor analysis of social media use and education. Int. J. Educ. Technol. High. Educ. 2019, 16, 32. [CrossRef]

22. Chang, M.L.D.; Suki, N.M.; Nalini, A. A Structural Approach on Students' Satisfaction Level with University Cafeteria. Asian Soc. Sci. 2014, 10, 202.

23. Hair, J.; Black, W.; Babin, B.; Anderson, R.; Tatham, R. Multivariate Data Analysis; Pearson Prentice Hall: Upper Saddle River, NJ, USA, 2010.

24. Zhou, Z.; Jin, X.-L.; Vogel, D.R.; Fang, Y.; Chen, X. Individual motivations and demographic differences in social virtual world uses: An exploratory investigation in Second Life. Int. J. Inf. Manag. 2011, 31, 261-271. [CrossRef]

25. Jeong, H. An investigation of user perceptions and behavioral intentions towards the e-library. Libr. Collect. Acquis. Tech. Serv. 2011, 35, 45-60. [CrossRef]

26. Lin, W.-S.; Wang, C.-H. Antecedences to continued intentions of adopting e-learning system in blended learning instruction: A contingency framework based on models of information system success and task-technology fit. Comput. Educ. 2012, 58, 88-99. [CrossRef] 
27. Al-Gahtani, S.S. Empirical investigation of e-learning acceptance and assimilation: A structural equation model. Appl. Comput. Inform. 2016, 12, 27-50. [CrossRef]

28. McQuitty, S.; Wolf, M. Structural equation modeling: A practical introduction. J. Afr. Bus. 2013, 14, 58-69. [CrossRef]

29. Teo, T.; Noyes, J. An assessment of the influence of perceived enjoyment and attitude on the intention to use technology among pre-service teachers: A structural equation modeling approach. Comput. Educ. 2011, 57, 1645-1653. [CrossRef]

30. Alumran, A.; Hou, X.-Y.; Sun, J.; Yousef, A.A.; Hurst, C. Assessing the construct validity and reliability of the parental perception on antibiotics (PAPA) scales. BMC Public Health 2014, 14, 1-9. [CrossRef]

31. Yang, F.; Tan, J.; Peng, L. The effect of risk perception on the willingness to purchase hazard insurance-A case study in the Three Gorges Reservoir region, China. Int. J. Disaster Risk Reduct. 2020, 45, 101379. [CrossRef]

32. Gefen, D.; Straub, D.; Boudreau, M.-C. Structural equation modeling and regression: Guidelines for research practice. Commun. Assoc. Inf. Syst. 2000, 4, 7. [CrossRef]

33. Steiger, J.H. Understanding the limitations of global fit assessment in structural equation modeling. Personal. Individ. Differ. 2007, 42, 893-898. [CrossRef]

34. Abuhassna, H.; Al-Rahmi, W.M.; Yahya, N.; Zakaria, M.A.Z.M.; Kosnin, A.B.M.; Darwish, M. Development of a new model on utilizing online learning platforms to improve students' academic achievements and satisfaction. Int. J. Educ. Technol. High. Educ. 2020, 17, 38. [CrossRef]

35. Hornbæk, K.; Hertzum, M. Technology acceptance and user experience: A review of the experiential component in HCI. ACM Trans. Comput. Hum. Interact. 2017, 24, 1-30. [CrossRef]

36. Ke, C.-H.; Sun, H.-M.; Yang, Y.-C.; Sun, H.-M. Effects of User and System Characteristics on Perceived Usefulness and Perceived Ease of Use of the Web-Based Classroom Response System. Turk. Online J. Educ. Technol. 2012, 11, 128-143.

37. Cidral, W.A.; Oliveira, T.; Di Felice, M.; Aparicio, M. E-learning success determinants: Brazilian empirical study. Comput. Educ. 2018, 122, 273-290. [CrossRef]

38. Budu, K.W.A.; Yinping, M.; Mireku, K.K. Investigating the effect of behavioral intention on e-learning systems usage: Empirical study on tertiary education institutions in Ghana. Mediterr. J. Soc. Sci. 2018, 9, 201. [CrossRef]

39. Phua, P.L.; Wong, S.L.; Abu, R. Factors influencing the behavioural intention to use the internet as a teaching-learning tool in home economics. Procedia Soc. Behav. Sci. 2012, 59, 180-187. [CrossRef]

40. Brusso, R.C. Employee Behavioral Intention and Technology Use: Mediating Processes and Individual Difference Moderators. Ph.D. Thesis, Old Dominion University, Norfolk, VA, USA, 2015. [CrossRef]

41. Islam, A.N. Investigating e-learning system usage outcomes in the university context. Comput. Educ. 2013, 69, 387-399. [CrossRef]

42. Park, S.Y.; Nam, M.W.; Cha, S.B. University students' behavioral intention to use mobile learning: Evaluating the technology acceptance model. Br. J. Educ. Technol. 2012, 43, 592-605. [CrossRef]

43. Kim, Y.; Lee, H.S. Quality, perceived usefulness, user satisfaction, and intention to use: An empirical study of ubiquitous personal robot service. Asian Soc. Sci. 2014, 10, 1. [CrossRef]

44. Machdar, N.M. The Effect Of Information Quality On Perceived Usefulness And Perceived Ease Of Use. Bus. Entrep. Rev. 2019, 15, 131-146. [CrossRef]

45. Ali, B.M.; Younes, B. The impact of information systems on user performance: An exploratory study. J. Knowl. Manag. Econ. Inf. Technol. 2013, 3, 128-154.

46. Fan, Y.; Chen, J.; Shirkey, G.; John, R.; Wu, S.; Park, H.; Shao, C. Applications of structural equation modeling (SEM) in ecological studies: An updated review. Ecol. Process. 2016, 5, 19. [CrossRef]

47. Ong, A.K.S.; Prasetyo, Y.T.; Lagura, F.C.; Ramos, R.N.; Sigua, K.M.; Villas, J.A.; Young, M.N.; Diaz, J.F.T.; Persada, S.F.; Redi, A.A.N.P. Factors affecting intention to prepare for mitigation of "the big one" earthquake in the Philippines: Integrating protection motivation theory and extended theory of planned behavior. Int. J. Disast. Risk PE. 2021, 63, 102467. [CrossRef]

48. Steinberger, P.; Eshet, Y.; Grinautsky, K. No Anxious Student Is Left Behind: Statistics Anxiety, Personality Traits, and Academic Dishonesty-Lessons from COVID-19. Sustainability 2021, 13, 4762. [CrossRef]

49. Al-Rahmi, A.M.; Shamsuddin, A.; Alturki, U.; Aldraiweesh, A.; Yusof, F.M.; Al-Rahmi, W.M.; Aljeraiwi, A.A. The Influence of Information System Success and Technology Acceptance Model on Social Media Factors in Education. Sustainability 2021, 13, 7770. [CrossRef]

50. Kim, S.; Kim, D.-J. Structural Relationship of Key Factors for Student Satisfaction and Achievement in Asynchronous Online Learning. Sustainability 2021, 13, 6734. [CrossRef]

51. Wang, T.; Lin, C.-L.; Su, Y.-S. Continuance Intention of University Students and Online Learning during the COVID-19 Pandemic: A Modified Expectation Confirmation Model Perspective. Sustainability 2021, 13, 4586. [CrossRef]

52. Prasetyo, Y.T.; Roque, R.A.; Chuenyindee, T.; Young, M.N.; Diaz, J.F.; Persada, S.F.; Miraja, B.A.; Perwira Redi, A.A. Determining Factors Affecting the Acceptance of Medical Education eLearning Platforms during the COVID-19 Pandemic in the Philippines: UTAUT2 Approach. Healthcare 2021, 9, 780. [CrossRef]

53. Prasetyo, Y.T.; Tanto, H.; Mariyanto, M.; Hanjaya, C.; Young, M.N.; Persada, S.F.; Miraja, B.A.; Redi, A.A. Factors Affecting Customer Satisfaction and Loyalty in Online Food Delivery Service during the COVID-19 Pandemic: Its Relation with Open Innovation. J. Open Innov. 2021, 7, 76. [CrossRef] 